A comparative approach to deer motif in the movies, The Red Deer and The Deer Hunter/ F. Kalpaklı (pp. 10961112)

\title{
62. Alageyik filmi ile Avcı filmindeki geyik imgesine karşılaştırmalı bir bakış ${ }^{1}$
}

Fatma KALPAKLI²

\begin{abstract}
APA: Kalpaklı, F. (2021). Alageyik filmi ile Avcı filmindeki geyik imgesine karşılaştırmalı bir bakış. RumeliDE Dil ve Edebiyat Araşttrmalar Dergisi, (24), 1096-1112. DOI: 10.29000/rumelide.995493.
\end{abstract}

\section{$\ddot{O} \mathbf{z}$}

Alageyik Yaşar Kemal’in ÜçAnadolu Efsanesi adlı üçlemesinin üçüncü destanıdır ve önce Atıf Yılmaz (1959), daha sonra da Süreyya Duru (1969) tarafından beyazperdeye uyarlanan eser çevre dostu ve doğa manzaralarıyla seyirciyi büyüleyen bir filme dönüşmüştür. Filmin kahramanı Halil (önce Yılmaz Güney, daha sonra da Cüneyt Arkın tarafından canlandırılan) bir türlü geyik tutkusundan ve geyiklerin sesleriyle yaptığı çağrıdan vazgeçemeyerek gerdek gecesinde bile kendini dağlara vuran bir geyik avcısıdır. Anadolu halkı biri bir geyiği, özellikle de bir alageyik yavrusunu incitirse, o kişinin Anadolu'daki hayvanların hayatına ve güvenliğine öncelik tanıyan sosyal ve ahlaki değer yargılarını hiçe saydığından ötürü lanetleneceğine ve iflah olmayacağına inanmaktadır. Bu doğa-dostu kültürel mirasa ve geçmişe sahip olan köy halkı film boyunca Halil’i sık sık uyararak, Anadolu insanının toprak etiği bağlamında, geyik öldürenlerin sonunun kötü olduğu konusunda onu açıca uyarırlar. Avcr ise James Fenimore Cooper'ın The Deerslayer/Geyikkatili (1841) adlı romanının beyazperdeye bir uyarlamasıdır ve yönetmenliğini 1978 yılında Michael Cimino yapmıştır. Avcı filminin kahramanı Michael da bir geyik avcısıdır ve geyik avında ahlaki açıdan inandığı tek atışta öldürme prensibini uygulamaktadır. Tıpkı Halil gibi o da doğayı, dağları, özellikle de geyikleri çok sevmektedir. Filmin ilerleyen sahnelerinde daha sonra gönüllü olarak Vietnam'a gitmek için Amerikan ordusuna katılır ve bu tecrübe onun hem geyik avını hem de insan avını/savaşı sorgulamasına sebep olur. Bu esnada, Amerikan vatanseverliği/kahramanlığı ile Batı'nın ata-erkil erillik kavramları ve vicdanı arasında kalan Michael dağlarda geyiklerin peşinden koşarak biraz huzur ve sükûnet bulmaya çalışmaktadır. Bir gün, dağdaki bir geyik Michael’ın yaşamın ölüm üzerine olan önceliğine ve kutsallı̆̆ına dayalı olan Amerikalı yerlilerin toprak etiğini yeniden keşfetmesine yardımcı olur. Bu nedenle, bu çalışmada, geyik motifi ve geyik avı temasına odaklanarak edebi eserlerin ve filmlerin toplumlarda çevre bilinci oluşturmadaki rolü ve ayrıca Alageyik ile Avcı filmleri üzerinden soyu tükenme tehlikesiyle yüz yüze olan geyiklerin koruma altına alınarak saylarının artırılmasında edebi eserlerden ve filmlerden nasıl istifade edilebileceği irdelenecektir.

Anahtar kelimeler: Alageyik, Avcı, Çevre Çalışmaları, Anadolu toprak etiği, Amerika toprak etiği

\section{A comparative approach to deer motif in the movies, The Red Deer and The Deer Hunter}

\begin{abstract}
The Red Deer is adapted from Yaşar Kemal's trilogy entitled The Three Anatolian Legend. It is directed first by Atıf Yılmaz in 1959 and ten years later by Süreyya Duru in 1969 and has become an
\end{abstract}

Bu çalışma, 4 Nisan 2016 tarihinde Hacettepe Toprak Etiği Araştırma Merkezi Geyik Sempozyumu’nda davetli konuşmacı olarak sunulan "Alageyik Filminde Geyik Motifi” adlı çalışmanın genişletilmiş halidir.

Doç. Dr., Selçuk Üniversitesi, Edebiyat Fkültesi, İngiliz Dili ve Edebiyatı (Konya, Türkiye), fkalpakli@gmail.com, ORCID ID: 0000-0002-0865-5373 [Araştırma makalesi, Makale kayıt tarihi: 05.0.2021-kabul tarihi: 20.09.2021; DOI: 10.29000/rumelide.995493]

Adres
RumeliDE Dil ve Edebiyat Araştırmaları Dergisi Osmanağa Mahallesi, Mürver Çiçeği Sokak, No:14/8 Kadıköy - ISTANBUL / TÜRKIYE 34714 e-posta: editor@rumelide.com tel: +90 $5057958124,+902167730616$
Address

RumeliDE Journal of Language and Literature Studies

Osmanağa Mahallesi, Mürver Çiçeği Sokak, No:14/8

Kadıköy - ISTANBUL / TURKEY 34714

e-mail: editor@rumelide.com,

phone: +90 5057958124 , +90 2167730616 
environment-friendly, scenic film with natural images. The protagonist of the movie, Halil (acted first by Yılmaz Güney in 1959 and then by Cüneyt Arkın in 1969) is a deer-hunter, who cannot ignore the call/voice of the reddeer and finds himself in the mountains even at the first night of his marriage. In Anatolia, people believe that if someone hurts a deer, especially a fawn, then s/he is cursed and doomed to go through very tough times as this person disregards the social and moral values, which prioritize the life and well-being of animals. Having this eco-friendly cultural heritage and background, all the villagers warn him quite often by explicitly stating that he will be cursed sooner or later within the context of land ethics of the Anatolian people. The Deer Hunter is adapted from James Fenimore Cooper's novel, The Deerslayer (1841). It is directed by Michael Cimino in 1978. The protagonist of the movie, Michael is also a deer-hunter, who follows the code of one-shot as a moral imperative during the deer-hunts. Just like Halil, Mike is also a lover of nature, mountains and especially of deer. Later, he enrolls in the American Army to go to Vietnam and begins to question human-hunts as well as deer-hunts. Torn between the concepts of native American heroism/American patriotism and Western patriarchal concepts of masculinity and his conscience, he tries to find peace and solitude by running after deer in the mountains. Meanwhile, a deer guides him in the mountains in order to help him rediscover the land ethics of America/native Americans, which prioritize the sacredness of life over death. Thus, in this study we will focus on the motif of deer and how the theme of deer-hunting is used to raise environmental consciousness and how literary works and movies are used to keep the endangered species of deer alive and increase the overall population of deer species with reference to The Red Deer and the Deer Hunter.

Keywords: The Red Deer, The Deer Hunter, Environmental Studies, land ethics of Anatolia, land ethics of America

\title{
Alageyik filmi ile Avcı filmindeki geyik imgesine karşılaştırmah bir bakış
}

\begin{abstract}
Yaşar Kemal'in Üç Anadolu Efsanesi adlı üçlemesinin üçüncü destanıdır Alageyik. Önce Atıf Yılmaz (1959), daha sonra da Süreyya Duru (1969) tarafından beyazperdeye uyarlanan eser4 Halil adlı bir geyik avcısının hayatını ve geyik tutkusunu konu almaktadır. Her iki filmin yapım tarihine bakıldığında 6olı yıllar5 olduğu ve tarihi olarak da Türkiye'de bu yıllarda bazı hayvanlar için koruma amaçlı rezerv alanları oluşturulmaya başlandığı görülmektedir. Orman ve Su İşleri Bakanlığı’nın “Tür Koruma Stratejisi” adlı raporunda ifade edildiği üzere, "[ü]lkemizde nesli tehlike altında olan türlerin korunmasına yönelik ilk çalışmalar 1960'lı yıllarda özellikle avcılık faaliyetlerinin hedefi olan yaban koyunu, yaban keçisi ve geyik gibi türler için rezerv alanları oluşturulmasıyla başlamıştır”. (Tür Koruma Stratejisi - Doğa Koruma ve Milli Parklar")
\end{abstract}

3 “1959 yılında düzenlenen 1. Türk Filmleri Yarışması’nda “Ala Geyik” filmi Atıf Yılmaz’a en başarılı rejisör ödülünü getirmiştir” (Baran, 76).

Bakını, Kara "Sinema'nın Yaşar Kemali".

Gülbün Onur, "Türk Filmlerinde Değișen ve Değișmeyen Karakterler/ Flat and Round Characters in Turkish Films” adlı makalesinde de belirttiği üzere 6o'ların sonunda ve 70’lerin başında toplumsal sorunlara gerçekçi bir bakış henüz çok yaygın değildi: Türk filmlerinin geleneksel repertuarında 6o'ların sonunda ve $70^{\prime}$ lerin başında yapılan filmler, toplumu komedi veya melodramatik trajedilerle eğlendirme amacı gütmektedir ve bu her iki akım da gerçekçilik akımı nosyonlarından çok uzaktır.... Bu bağlamda da Alageyik filminde ele alınan konular ve geyik canının kutsallı̆̆ı ve daha geniş çerçevede hayvan hayatına duyulan saygı ve film sayesinde toplumda uyanan çevre bilinci kayda değerdir.

Adres Address

RumeliDE Dil ve Edebiyat Araştırmaları Dergisi $\quad$ RumeliDE Journal of Language and Literature Studies

Osmanağa Mahallesi, Mürver Çiçeği Sokak, No:14/8 Osmanağa Mahallesi, Mürver Çiçeği Sokak, No:14/8

Kadıköy - İSTANBUL / TÜRKIYE 34714 Kadıköy - ISTANBUL / TURKEY 34714

e-posta: editor@rumelide.com $\quad$ e-mail: editor@rumelide.com,

tel: +90 $5057958124,+90216773$ o 616 phone: +90 505 7958124, +90 216773 o 616 
A comparative approach to deer motif in the movies, The Red Deer and The Deer Hunter/ F. Kalpaklı (pp. 10961112)

Bu makalede, özellikle başrollerinde Cüneyt Arkın ve Mine Mutlu'nun rol aldığı 1969 yllı yapımı Alageyik filmi üzerinde durulacaktır, ancak zaman zaman 1959 yapımı ve başrollerinde Yılmaz Güney ile Pervin Par’ın oynadı̆̆ı filmin ilk versiyonu6 ile de karşılaştırmalar yapılacaktır.

Halil dağlarda geyik avlamayı ve bir de sözlüsü Zeynep’i çok sevmektedir. Ancak, filmin başından itibaren sık sık geyik avlamanın uğursuzluk getireceği üzerinde durulur ve Halil’in annesi,

"Ey oğul oğul. Gel vazgeç şu geyik avından. Yuva yıkanının yuvası olmaz. İflah olmazsın. Sonu iyi gelmez. Gel vazgeç. Bak baban da bu yüzden iflah olmadı. Ne yapacaksın bunca geyik postunu. Yüreğim razı değil. Atalar geyik avı tekin değil demiş. Bugün olmazsa; yarın bir iş gelir geyik avlayanın başına. Kurbanın olam oğul, terk et bu işi" (Alageyik, 1969)

diyerek Halil'i geyik avından alıkoymaya çalışır.

Ancak, geyikler ve dağlar7 Halil için bir tutkudur (bakınız Şahin, “Alageyik ile Avcının Ölümcül Dansı”) ve ne yaparsa yapsın bu tutkusunu bir türlü dizginleyemez. Oysaki Anadolu'da geyik canına kıymanın uğursuzluk ve musibet getireceğine dair güçlü bir inanç vardır ve hem nişanlısı Zeynep, hem de annesi film boyunca Halil'e sık sık bu durumu hatırlatırlar. Halil dağlarda geyik peşinde koşarken, Sarıca köyü Ağası, Karaca Ali'de Halil’in nişanlısı ve köy ahalisinin “ceylan gözlü8” olarak nitelendirdiği Zeynep’in peşine düşer. Böylece filmde Shakespeare’in birçok oyununda da görüldüğü gibi "geyik av” ile "kadın avı" arasında bir paralellik kurulur. Shakespeare'in ve Yaşar Kemal'in hikâyelerinin yanı sıra kutsal kitaplarda9 da geyik, ceylan avına değinilir. Örneğin, Kuran-ı Kerim'de bir av hikâyesi anlatılır. İhraml110 iken yasak olduğu halde, bazı insanlar ceylan avlamak isterler. Bu da ilahiyatçllar için "sınırı aşmayı ve helalden harama kaymayı temsil eder" (Cuma Sohbetleri). Bunu da filmde, Karaca Ali’nin sözlü bir kızı, ceylan gözlü Zeynep’i istemesiyle ilişkilendirebiliriz. Normal şartlar altında, Anadolu kültüründe, kız istemek ayıp, günah değildir, fakat sözlü bir kızı istemek sınırı aşıp, harama meyletmektir, tıpkı yiyecek ihtiyacı ${ }^{11}$ olmadığı halde insanların ceylanları sırf tutkuları yüzünden

6 Yllmaz’ın sonraki önemli filmi, 1959 yılında çektiği “Alageyik”tir. Bu filmle birlikte, Yılmaz’ın, Yaşar Kemal'le yıllar sürecek işbirliği de başlar. Halit Refiğ ve Yılmaz Güney'le beraber, Yaşar Kemal'in bir öyküsünden uyarladıkları film, bir halk masalından yola çıkar; geyik avına düşkün bir gencin av tutkusu ve sevdiği kadınla arasındaki ilişkiler üzerine kuruludur... Yılmaz, bu ilk folklor denemesinde, oba insanlarının yaşayışını ve geleneklerini beyazperdeye aktarması ile değişik ve kendi ölçüleri içinde başarılı sayılabilecek bir sonuca ulaşır (Tunalı, 52).

$7 \quad$ Bedri Rahmi Eyuboğlu da Yaradan'a Mektuplar adlı eserinde, Halil’in dağlarda duyduğu mutluluğa benzer bir duygu içindedir; "Şair yaşamın evrensel ve değişmez döngüsüne, modern bir mistik duyuşla yaklaşır ama mutasavvıflar gibi bu dünyadan gideceği günü tevekkülle beklemez aksine meyveleri, hayvanları, dağları, tepeleriyle yeryüzünde yaşamayı ister, cenneti arzulamaz. Bedri Rahmi’nin şiirlerinde doğanın her bir öğesi, insana yaşama coşkusu verecek güzelliktedir. Doğa, sair için bereketle eștir" (Alpaslan: "Türk Siirinde Doğa Algısı”, 2014, s. 90).

8 Karacaoğlan da bir şiirinde güzeli "ceren bakışlı" olarak tanımlar (Aktaran Alpaslan 2014: "Türk Şiirinde Doğa Algısına Dair Betimleyici Bir Bakış, s. 81) ve ceren halk arasında ceylan demektir.

$9 \quad$ Tevrat'da Tanrı ile Eyup arasındaki konușmada Tanrı geyiklerle ile ilgili olarak şunları dile getirir: Geyiklerin yavruladığı vakti sen mi bekliyorsun? Doldurdukları ayları sen mi sayıyorsun? Yahut doğurdukları vakti sen bilir misin? Çökerler, yavrularını doğurururlar. Ağrılarından kurtulurlar. Yavruları kuvvetlenir, kırda büyürler; Çıkıp giderler de, bir daha dönmezler ( Eyup /BAP $39(2015,547)$ ).

10 İhrama giren kişi için normal zamanlarda haram olmayan giyim-kuşam, cinsel hayat ve avlanmayla ilgili haramlar söz konusudur. Bu yasakların çiğnenmesi, yasağın çeşidine göre değişen şekillerde cezayı gerektirir. (“ỉhram Nedir?”)

İhtiyaç olmadan hayvanların öldürülmesi ve doğanın haklarının ihlali hakkında daha fazla bilgi almak için aşağıda bir bölümü verilen Tarık Masud Quadir'in "Islam and Sustainability: The Norms and The Hindrances" adlı makalesine bakınız:

Kuran'da ve hadislerde, hayvanların aç bırakılması, ihtiyaç olmadan öldürülmesi ve herhangi doğal bir kaynağın kirletilmesi, boşa kullanılması, istismar edilmesi, kirletilmesi Allah’a karşı gelmek olarak değerlendirilerek yasaklanmıştır; aynı şekilde, [doğaya] haksızlık etmek, Allah'ın işaretlerine saygısızlık etmek, [doğanın] denge[sini] bozmak ya da doğaya zarar vermek (fasad) Allah tarafindan şiddetli bir şekilde kınanmıştır. Çok iyi bilinen bir ayette de uyarıldığı üzere (Quadir, 123), "Karada ve denizde bozulma (fasad) insanın kendi eliyle kazandıkları yüzündendir, böylece Tanrı insanlara onların yaptıklarının bir kısmını tatmalarına müsaade eder ki belki [Allah’ın yoluna] geri dönerler” (Kuran 30:41; 2:205-6). (Aktaran Quadir, 123-124)

In the Quran and the Hadith, unnecessary killing, denying nourishments to animals, and wasting, exploiting, dirtying, or polluting any natural resource are forbidden as a form of disobedience of God; likewise, committing injustice, disrespecting the signs of God, upsetting the balance, or corrupting (fasad) of nature are acts condemned by God in the

Adres | Address

RumeliDE Dil ve Edebiyat Araştırmaları Dergisi Osmanağa Mahallesi, Mürver Çiçeği Sokak, No:14/8 Kadıköy - İSTANBUL / TÜRKIYE 34714 e-posta: editor@rumelide.com tel: +90 $5057958124,+902167730616$

RumeliDE Journal of Language and Literature Studies Osmanağa Mahallesi, Mürver Çiçeği Sokak, No:14/8

Kadıköy - ISTANBUL / TURKEY 34714

e-mail: editor@rumelide.com,

phone: +90 $5057958124,+902167730616$ 
avlamaları gibi ve hele hele bunu bir de ihramlı iken yapmaya kalkışmaları gibi. Bu nedenlerden ötürü, hem romanda hem de filmde "insanın yok edici gücünü doğaya [ve toprak ana ile özdeşleştirilen kadına/Zeynep'e] yönelttiğinde nasıl büyük bir felaketle karşılaşılacă̆ı, zincirleme bir çizgiyle” (Alpaslan “Cengiz Aytmatov'un Elveda Gülsarı" 2014: 15) işlenmiştir.

Zeynep de tıpkı bir geyik gibi "güzel, narin ve ürkek"12"tir ve her dakika Halil'e dağlarda, avlanırken bir şey olacak diye yüreği pır pır etmektedir. Nitekim bu korkusu da boşuna değildir. Karaca Ali Zeynep’i ve Halil'i ayırmak için adamlarıyla beraber dağlarda pusular kurar ve ilginç bir şekilde Halil ala bir geyiğin sayesinde kurtulur. Geyik Halil'e bir görünüp, bir kaybolarak ona adeta yol gösterir. Bu da aslında Türk kültüründe asırlardır yer etmiş bir temadır. Sayın Karadavut ve Yeşildal, Türk kültüründe geyiğe yüklenen anlamlar ile ilgili olarak "Anadolu-Türk Folklorunda Geyik” başlıklı yazılarında geyiğin bazı özellikleriyle öne çıktığını vurgularlar: "[Geyiğin] türeyiş hikayelerindeki rolü, av hayvanı ve yol gösteri olarak geyik, geyiğin metamorfoz ya da şekil değiştirme yeteneği, zaman zaman hükmedilen, zaman zaman da hükmeden hayvan olarak geyik, ayrıca geyiğe kutsallık atfedilmesi ve geyiğin betimlemelerde kullanılması" gibi (bakınız Karadavut ve Yeşildal: 2007, s.103-111).

Alageyik filminde ise geyik Halil'e hem dağlarda hem de ruhsal gelişim yolculuğunda ona yol gösterir. Alageyik dağlarda ${ }^{13}$ Halil’i peşinden koşturarak, Halil’i bir nevi içsel bir yolculuğa çıkarır. İnsanlardan uzak, dağlarda doğa ile ve kendi ile baş başa kalan Halil farkında olmaksızın kendini de tanımaya başlar. $\mathrm{Bu}$ da İngiliz edebiyatı severlerin çok aşina olduğu ve ünlü İngiliz romancısı Thomas Hardy’nin eserlerinde sık sık vurguladığı "doğaya yakın olan insanın özüne de yakınlaştığı" tezini güçlendirmektedir. Bu süreçte, hem izleyiciler hem de Halil, onun "hayattaki en büyük tutkusunun geyikler" olduğuna tanık olur. Fakat Halil’in iç dünyasında "geyik öldürmeye karşı olan zaafı" ve "hayvanlar üzerinde egemenlik kurma çabası" (Alpaslan “Cengiz Aytmatov’un Elveda Gülsart: 2014, 15) nihayetinde "geyiğe sahip olma isteği" bir nevi kendi sonunu da getirir aslında. Bu konuyla ilgili olarak çeşitli eleştirmenler "geyiklerin canına kıyma" ile ilgili olarak şu satırları dile getiriyor:

Türk insanının düşüncesinde kutsal ve iyilik getiren bir hayvan olarak kabul edilen geyiğin avlanmasının çoğu zaman uğursuzluk getireceğine inanılmaktadır. Çünkü geyik vahşi bir hayvandır. İlkel insanın zihninde evcil hayvanlar insanlar topluluğuna aitken, vahşi hayvanlar tanrılar topluluğuna aittir der Bonnefoy (2000: s.375).

$\mathrm{Bu}$ inanışla ilgili olan "Alageyik” efsanesinde, geyik avına meraklı olan genç, dügün gecesi gelini ortada bırakıp seslerini duyduğu geyiklerin peşinden gider ve içlerine su birikmiş oyuklardan birine düşüp boğularak can verir diye belirtir Seyidoğlu (1985: s. 137).

Bir Erzincan Efsanesi’nde [de] kadının sağdığı geyiği öldüren avcılar, kadının duasıyla taş kesilirler diye anlatır Sakaoğlu (1992: s. 76).

Alageyik efsanesinin film versiyonunda ise Halil düşmanları tarafından pusuya düşürülerek vurulur, böylece "ava giden avlanır" atasözünde olduğu gibi can almak isterken, kendi canından olur. Burada kutsal bir değer olan "can” (bakınız Cüceloğlu, Damdan Düşen Psikolog) kavramına da değinmek istiyoruz.

strongest terms. As a famous verse warns (Quadir, 123), "Corruption (fasad) has appeared on the land and sea because of that which men's hands have earned, that He may let them taste some of that which they have done, that haply they might return [to the path of God]"(Quran 30:41; also 2:205-6). (qtd.in Quadir, 123-124)

(bakınız ayrica Wright, "Deer and Deer-Hunting in Texas", The American Naturalist , 466).

13 Geyik dağların, vadilerin ve sarp kayaların görünüp kaybolan, sihirli ve en güzel bir hayvandır. Büyüleyen, insanı hayale kaptıran ve ulaşılmayan bir hayvandır" (Ögel, 2014, 129).

Adres | Address

RumeliDE Dil ve Edebiyat Araştırmaları Dergisi Osmanağa Mahallesi, Mürver Çiçeği Sokak, No:14/8 Kadıköy - ISTANBUL / TÜRKIYE 34714 e-posta: editor@rumelide.com tel: +90 505 7958124, +90 2167730616

RumeliDE Journal of Language and Literature Studies Osmanağa Mahallesi, Mürver Çiçeği Sokak, No:14/8

Kadıköy - ISTANBUL / TURKEY 34714

e-mail: editor@rumelide.com,

phone: +90 505 7958124, +90 2167730616 
A comparative approach to deer motif in the movies, The Red Deer and The Deer Hunter/ F. Kalpaklı (pp. 10961112)

Türklerde şamanizmden bu yana tıpkı Kelt ve Kızılderili kültürlerinde de olduğu gibi her şeyin "bir ruhu ve canı olduğu" inancı olgusundan yola çıkarsak ve buna kutsal dinlerde "yaşayan, can taşıyan her şeye sayg”" öğretisini de ekleyecek olursak Halil burada geyik canına, özellikle de neredeyse bir tabu olan "yavru geyik" canına kastettiği için bir nevi evrendeki, "doğadaki ilahi adalet döngüsünce" cezalandırılmaktadır. "Aynı inanışın [diğer bir] ürünü olan 'Yavru Ceylan' efsanesinde, yavru bir ceylanı öldüren Sarı Avcı, eve vardığında küçük oğlunun öldüğünü görür ve bundan sonra bir daha ceylan avlamaz"(Karadavut \& Yeşildal, 2007, 105).

$\mathrm{Bu}$ temanın beyazperdeye de taşınmasıyla, sanki adeta halka modernleşme ile beraber unutulan ve kökleri Şamanizm'e kadar dayanan bu kültürel değerler yeniden hatırlatılmakta ve "soyu tükenme tehlikesi ile karşı karşıya olan geyik, ceylan” gibi memeli hayvanlar korunmaya çalışılmaktadır.

Filmde seyirciye geyiğin kutsallığı, hayvan hayatının kutsallığı vurgulanarak ve dağlardaki güzel geyik ve alageyik görüntüleriyle, seyircilerin bilinçaltına seslenilerek, seyirci üzerinde geyiğe karşı sempati uyandırılmaktadır. Ayrıca, filmde Halil’i dağda pusuya düşürmek için kullanılan geyik sesi de doğadan uzak, şehirlerde yaşayan seyirci üzerinde geyiğe karşı ilgi ve sempatiyi uyandırarak modern insanın hayvan sevgisinin artmasına sebep olmaktadır ve bu nedenle filmde kullanılan doğa görüntülerinin ve yabanıl seslerin son derece işlevsel olarak kullanıldı̆̆ı görüşündeyiz. Filmdeki dağlardaki ve köydeki doğal ortam ile şu nokta vurgulanır: "doğanın bütün öğeleri değerlidir, özeldir, her biri yaşamın gücünü ve güzelliğini hissettirir; hiçbir öğesi alelade veya önemsiz değildir” (Alpaslan: Doğa Algısı 2014, 91) ve bu nedenle, Anadolu toprak etiğinde gelecekteki geyik nüfusunun teminatı olan yavru bir geyiği avlamak sınırı aşmak ve lanetlenmeyi göze almak demektir. Doğanın tüm öğelerinin bir bütün olarak korunması gerekliliği vardır ve bu sorumluluk da en başta o yörede yaşayan insanlara düşmektedir. "Doğaya uyumlu yaşadığında insan, doğanın kabullendiği bir öğedir ama doğanın uyumunu bozduğunda [köyde, geyik avlayan iflah olmaz inancı doğrultusunda filmde de vurgulandığı üzere] kendi felaketinin de yaratıcısıdır” (Alpaslan: “Cengiz Aytmatov’un Elveda Gülsarı, Dişi Kurdun Rüyaları” 2014, 24).

Filmde mekân olarak da "Antalya dağları" seçilmiştir (bakınız "Alageyik filmi”) çünkü dünyada en saf yabani alageyiklerin bulunduğu tek yer Antalya ${ }^{14}$ 'dır ve bu geyiklerin takip edilmesi ve avlanması çok zordur.

Alageyiğin avlanması, ele geçirilmesi zor olduğundan Halil'in geyik tutkusu da her geçen gün artmaktadır. Bu nedenle, çok yaman bir çelişkidir bu, geyik avındaki başarısı köy halkının gözünde onun ne kadar yiğit ve eril olduğunu simgelemektedir. Avda elde ettiği geyik etini köy meydanına getirir Halil ve tüm köy halkı hep beraber taze geyik etini yer. Halil burada hem avcı hem de köyüne, ocağına ekmek getiren ve bunu dost düşman demeden herkese gani gani ikram eden, cömertçe halkını besleyen "yiğit" konumundadır. Ancak, aynı zamanda geyik avının uğursuzluk getireceği inancı da köyde yer etmiştir ve

14 “dünyada en saf yabani alageyiklerin bulunduğu tek yer Antalya'dır ve yöre halkı tarafindan [ala geyiğe] Benekli geyik] adı da verilmektedir. [Bu geyik türü] [s]onradan insanlar tarafından [...] bütün Avrupa'ya yay[gınlaştırılmıştır]. [Alageyikler] İran'ın batı kıyıları ötesinde Asya'da doğal olarak bulunmazlar. Evcil ve yarı evcil popülasyonları, Avrupa başta olmak üzere değişik bölgelerdeki doğal parklarda ve korunaklı avlaklarda bulunan gözde bir türdür. Yabanileri çok ürkektir ve en ufak bir ses duyumunda ormanda izini kolayca kaybettirebilmektedir ve yaşam süreleri 12 yıl kadardır" ("Alageyik"; "Hayvanların Bilmediğiniz Özellikleri”). Alageyik ya da Yağmurca geyikgiller familyasından, göçmen olmayan ve sürü oluşturan, kürek boynuzlu ve benekli... bir geyik türüdür. Evcil ve yarı evcil popülasyonları doğal parklarda ve korunaklı avlaklarda kalabalık sürüler hâlinde bulunur. Antalya gibi gerçek yabani ortamlarında kalabalık sürü oluşturmazlar ve büyük bir erkeğe bağlı daha ufak sürüler, "harem" hâlinde toplanırlar. Görme duyuları diğer geyik türlerine göre daha iyi gelişmiştir... İhtiyatlı olan bu hayvanların izlerinin takip edilmesi kolay değil ve avlanması zordur.[3] (“Alageyik").

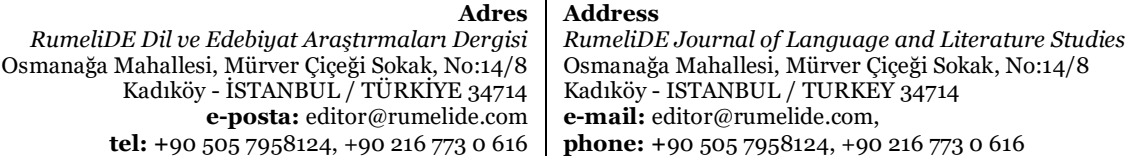


bu nedenle bir taraftan da Halil'in geyik avı tutkusu pek iyiye yorulmaz ve köy halkı da çelişki içindedir. Halil köy halkınca bir taraftan kahraman, bir taraftan da geyiklerin lanetine ${ }^{15}$ uğrayabilecek biri olarak görülmektedir ve bundan ötürüdür ki hem Halil’in hem de köyün akıbetinden korkarlar. Diğer bir deyişle, filmde "ne hayvanlar ne de insanlar kendini güvende hissetmektedir". Alageyik filminde geyiklerin dağlarda rahatsız edilmesiyle insanların köyde eşkıyalarca rahatsız edilmesi arasında böylece paralellik kurulmaktadır. Ayrıca, Halil aracılığıyla "[s)ilah... gibi araçlar kullanarak avlanan insanoğlunun bütün hayvanların doğal avlanma biçimlerinin dışında ve üstünde bir güç kullandığı vahşeti sergilenir" (Alpaslan “Cengiz Aytmatov'un Elveda Gülsart: 2014, 15) ve bu durumun da "doğacıl olmadı̆̆ı" (Alpaslan "Cengiz Aytmatov'un Elveda Gülsarı: 2014, 16) vurgulanır. Silahlı insana karşı geyik çırılçıplak, savunmasızdır adeta. Bu adil bir dövüş değildir. Geyiğin genel özellikleri ile ilgili olarak Hülya Dündar Şahin ise bir yazısında şu noktaların altını çizmektedir:

[Geyik]...[s]evimli, çevik, hassas ve içli bir hayvandır. İnce zarif bir vücuda sahip ve ürkektir. İnsandan kaçar, peşinden sürüklediği insanı dermansız bırakır. Tenha yerlerde yaşar. Avlayan iflah olmaz, avlanmış geyiğin gittiği ev tarümar olur, yerinde ot bitmez. Bedduası avcının soyuna da etki eder. Mukaddes bir hayvandır. Kurt gibi aniden ortaya çıkar ve çoğu kere insanlara doğru yolu gösterir. Birdenbire ortadan kaybolur. Mutlu sona erdiricidir. Sevgi perisidir. Totemdir, ruhların üzerinde dolaştığı ilahi bir varlıktır. Tanrı’nın elçisidir. Gökte dolaşan yarı ilahi yaratıktır.(s.71)

Tıpkı bu alıntıda belirtildiği üzere "geyiği avlayan iflah olmaz" ve "hayvan haklarının ihlali”, "[i]nsanın kendi dışındaki canlılara karşı acımasızlığı, sadece hayvanları değil, insanları da zorlamakta, ağır bedel ödetmektedir” (Alpaslan “Cengiz Aytmatov'un Elveda Gülsarı: 2014, 23), ancak filmde de vurgulandı̆̆ üzere, geyik aynı zamanda yol göstericidir ${ }^{16}$ de ve Halil’e dağlarda yol göstererek eşkiyalardan, Ağa ve adamlarından kurtulmasına yardımcı olur. Filmde, alageyik efsanesinde olduğu gibi Halil ölmez, sadece yaralanır ve böylece hikâyenin sonu izleyiciye biraz yumuşatılarak verilir. Halil filmin sonunda Zeynep’in yanında olacağına söz verir, artık aklı başına gelmiştir. Böylelikle, geyik onları da mutlu sona erdirmiştir. Hülya Dündar Şahin’in yazısında vurguladığı üzere "sevgi perisi olarak” sevenleri bir araya getirmiştir.

Filmin 1959 ve 1969 versiyonları karşılaştırıldığında, başrollerinde Yılmaz Güney17’in oynadı̆̆g Alageyik filminde yerel müziklerin ve yerel kültür öğelerinin daha ön planda olduğu gözlenmektedir. Alageyik’in her iki film versiyonu ile ilgili olarak Yaşar Kemal'in direkt bir eleştirisine ya da yorumuna rastlayamasak da, arşivlerde film eleştirmenlerince yapılan yorumlardan romandan sinemaya yapılan adaptasyonu başarılı buldukları görülmektedir. Bu bağlamda, Agah Özgüç filmin ilk versiyonu ile ilgili olarak,

1959’a gelince doğrudan doğruya bir Yaşar Kemal dünyası üzerine kurulmuş bir film görüyoruz. Bu, Atıf Yılmaz'ın yönettiği ve senaryosunu Hafit Refiğ’le Yılmaz Güney'le ortaklaşa yazdığı "Ala Geyik”tir. Yılmaz Güney’in de başrolünü oynadığı "Ala Geyik”, bir öykü olarak genel yapısı içinde destansı özellikler taşır. Ve Atıf Yılmaz’ın sineması da bu masalsı içeriğe uygundur kuşkusuz. Geyik avına tutkun Âli’yle [Bu şekilde yazılmış] yavuklusunun sevda öyküsü üzerine kurulan “Ala Geyik”te

15 Burada iki karşıt düşünce mevcuttur, Halil’in bol bol geyik eti ikram edebilmesinin ardında da diğer taraftan "hakkına razı olmayan, daima daha fazlasını isteyen, doğayı sınırsızca ve sorumsuzca kullanarak tüketen, dinginliği ve dengeyi bozan bütün eylemlerin kaynağı insandır” (Alpaslan “Cengiz Aytmatov’un Elveda Gülsarı: 2014, 17) görüşünü destekleyebilecek bir husus da mevcuttur ve köylüler belki de bu yüzden de Halil için endişelenmektedirler.

16 Satı Kumartaşlığlu, "Folklorumuzda geyik, avcıları ve veli şahsiyetleri mistik bir mekâna doğru yönlendiren bir aracı ve kılavuz hayvan olarak bilinir" (2016, 137) diye ifade etmektedir. Ayrıca, "Geyikler yılda bir defa üreme dönemlerinde boynuzlarını düşürürler ve yerine bir çatal fazlasıyla yenisini çıkarırlar. Bu nedenle geyik boynuzları 'yenilenmeyi' ve 'ölümsüzlüğü’ temsil etmektedir. Geyik boynuzlarının türbeleri ziyaret eden hastalara sürülmesi, boynuzların bu simgesel anlamı ile ilgilidir" $(2016,137)$.

17 Atıf Yılmaz’n 1959'da çektiği Alageyik, Bu Vatanın Çocukları'ndan sonra Güney'in oyuncu olarak 2. Filmidir. Dönemin yetkin sinema eleştirmeni Ali Gevgilili, Vatan gazetesindeki köşesinde yazdığı yazıda söyle der: "Atıf Yılmaz'ın Alageyik’te başrolü verdiği genç oyuncu Yllmaz Güney, davranışlarıyla yarınından umut vermektedir” (Varol, 70).

Adres | Address

RumeliDE Dil ve Edebiyat Araştırmaları Dergisi Osmanağa Mahallesi, Mürver Çiçeği Sokak, No:14/8 Kadıköy - İSTANBUL / TÜRKIYE 34714 e-posta: editor@rumelide.com tel: +90 $5057958124,+902167730616$

RumeliDE Journal of Language and Literature Studies Osmanağa Mahallesi, Mürver Çiçeği Sokak, No:14/8

Kadıköy - ISTANBUL / TURKEY 34714

e-mail: editor@rumelide.com,

phone: +90 505 7958124, +90 2167730616 
A comparative approach to deer motif in the movies, The Red Deer and The Deer Hunter/ F. Kalpaklı (pp. 10961112)

Atıf Yılmaz, anlatım ve folklorik çalışmalarıyla dikkati çekerken, Yılmaz Güney de oyuncu olarak ilk işaretini verecektir (1992:4).

diye belirtmektedir.

Alageyik filminin 1959 yapımında, Yılmaz Güney’in de fiziksel özellikleri açısından buğday tenli, bıyıklı tam bir Anadolu erkeği tiplemesine uyması ve ataerkil avcı toplumlardaki erillik kavramının filmde ön plana çıkartılmasında filmin yönetmenince fonksiyonel olarak kullanılmış olabilir diye düşünüyoruz. Nitekim, filmde bir ara Halil, dağlara çıkıp geyik avlamaktan vazgeçmiştir. Düşmanları/ağanın adamları bunun üzerine Halil için, “[k]orkudan geyik avına çıkamıyor. Karılar gibi oturup bardak nakışlıyor”, diyerek Halil’i kışkırtarak tekrar dağa çıkmasını sağlarlar ve "Üç Ceylan"18 Dağı’nda pusu" kurmayı planlarlar. On yıl sonra, Cüneyt Arkın'ın rol aldığı Alageyik filminde ise avcılık ve erillik arasındaki bağa değinilmekte, fakat bu kadar vurgu yapılmamaktadır.

Diğer taraftan, ilginç bir şekilde, filmde zaman zaman avcıllk erillik göstergesi olarak onore edilirken, film boyunca çekilen dağlardaki geyik ve doğal imgelerle seyirci üzerinde ters bir etki yaratılmakta ve bu güzellikler aracılığıyla izleyici üzerinde "doğa sevgisi" ve filmin sonuyla da vurgulandığı üzere "hayvanları koruma" isteği uyandırılmaktadır. Seyirci, avcı Halil'den çok, dağlarda ona yol gösteren alageyikle bütünleşmekte ve geyiğin rehberliği, geyiğin içgüdüleri seyircinin hem takdirini toplamakta hem de bu yolla izleyici tıpkı Cengiz Aytmatov'un Dişi Kurdun Rüyaları romanında olduğu gibi (bakınız Alpaslan, "Cengiz Aytmatov’un Elveda Gülsarı, Dişi Kurdun Rüyaları, Ebedi Gelin: Dağlar Yıkıldığı Zaman Romanlarında Hayvan Zihni”) geyiğin duygularını okuyabilmektedir.

Nitekim, filmin ana karakteri de "bir geyik avcısından bir geyik aşığına dönüşmüş" ve filmin sonunda "[t]övbeler tövbesi geyik avına” demektedir. Bugünkü istatistiklere bakıldığında da Alageyik filmi gibi hayvan ve doğa sevgisini aşılayan çalışmaların, çevre bilincinin ${ }^{19}$ oluşmasına katkıda bulunduğu söylenebilir. Sunulan bir rapora göre:

Türkiye'de ilk defa av ve yaban hayatı çalışmaları Antalya Orman Bölge Müdürlüğüne bağlı Düzlerçamı bölgesinde 1966 yılında başlamıştır. Senelerce bilinçsiz ve acımasız sürdürülen avcılık nedeni ile nesilleri yok olma sınırına gelen ve sadece Türkiye'de Düzlerçamı'nda 7 baş kalan alageyikler koruma çalışmalarıyla 2010 yılında 300-400 başa ulaşmıştır. (“Alageyik")

Sonuç olarak diyebiliriz ki çevre ve çevre sorunları ile ilgili edebi eserlerin sinemaya uyarlanmasıyla daha geniş kitlelere ulaşılabilmekte ve soyu tükenme tehlikesiyle karşı karşıya olan daha birçok hayvan çeşitinin korunması için alınması gereken tedbirler ve bunların eyleme dökülmesinde sinema, daha geniş bağlamda bugün dördüncü güç olarak adlandırılan medya önemli bir rol oynamaktadır ve "Alageyik filmi de bunun güzel bir örneğidir”. Devletçe alınan tedbirler ve bunun sinema yoluyla da pekiştirilmesi sonucu 70'li yıllardan bu yana alageyiklerin sayısında bir artış gözlemlenmiştir. Bu da Özdağ'ın Çevreci Eleştiriye Giriş²o kitabında ve Kadim programında belirttiği üzere, bilim tek başına çevreyi korumada yetersiz, kuru kalmaktadır ve çevre bilincinin halka yayılmasında edebiyatın ve edebi eserlerin (ve bunun bir uzantısı olarak da sinemanın) önemli bir rolü vardır argümanını destekler niteliktedir. Bu bağlamda, "Alageyik filminde, seyircilere (zaten eski Şaman Türk kültüründe de

18 Alageyik filminin 1959 yapımında, yer isimlerinde de geyik ve ceylan kelimeleri kullanılarak, geyik imgesine olan vurgu güçlendirilmektedir.

19 Bakınız Opperman ve Özdağ’n "Introduction: New Connections in Ecocriticism”, The Future of Ecocriticism: New Horizons. (1-8).

20 Esasen çevreci eleştirmenler, çevre krizinin çözüm bulması için salt bilimin işe yaramayacağını sıklıkla dile getirirler. Bu eleştirmenlere göre bilimin dili mekaniktir, sıkıcıdır, duygulardan yoksundur; insanın doğaya olan tavrında gereken değişikliği sağlamaya yetmez. Doğa korumada esas fark yaratacak olan ruhumuza seslenen ve böylelikle içsel bir değişime olanak tanıyan edebi eserlerdir (Özdağ, 2014, 19).

Adres $\mid$ Address

RumeliDE Dil ve Edebiyat Araştırmaları Dergisi $\quad$ RumeliDE Journal of Language and Literature Studies Osmană̆a Mahallesi, Mürver Ciçeği Sokak, No:14/8 $\quad$ Osmanağa Mahallesi, Mürver Çiçeği Sokak, No:14/8

Kadıköy - İSTANBUL / TÜRKIYE 34714 Kadıköy - ISTANBUL / TURKEY 34714 e-posta: editor@rumelide.com $\quad$ e-mail: editor@rumelide.com, tel: +90 $5057958124,+90216773$ o 616 phone: +90 505 7958124, +90 216773 o 616 
varolan) geyiğin, geyik canının, hayvan hayatının kutsallığı hatırlatılarak izleyici üzerinde bir çevre bilincinin oluşmasına katkıda bulunulmaktadır. Filmde sık sık tekrarlanan geyik avlayan iflah olmaz cümlesi ile de "doğanın her bir öğesinin değerinin farkına varan, doğanın içinde insanoğlunun sadece küçük bir parça olduğunu bütün varlığıyla hisseden” (Alpaslan: 2014, “Türk Şiirinde Doğa Algısı...”, 90) ve hissettiren bir mentalite ile karşılaşıyoruz ki bu doğadaki diğer canlıların yaşam hakkını ihlal etmeden, doğayla uyum içinde yaşama prensibinin hem izleyiciye hem de hayata aktarılması açısından son derece önemlidir.

Geyik motifinin ele alındığı bir diğer film ise yönetmenliğini Michael Cimino’nun yaptığı ve senaryosunu yine Michael Cimino'nun ve Deric Washburn'un yazdığı 1978 yılı Amerikan yapımı, başrollerinde Robert De Niro ile Meryl Streep’in yer aldığı Avcı/The Deer Hunter (bakınız “Avcı”, beyazperde ve sinemalar.com) filmidir. Avcl/The Deer Hunter (1978) filmi, James Fenimore Cooper'in Geyik Katili/The Deerslayer (1841) adlı romanından beyaz perdeye uyarlanmıştır. Film esas olarak Vietnam Savaşı'nı konu olarak almaktadır ve bunu yaparken

\begin{abstract}
Vietnam Savaşı'nı tasvir etmek için iki metafor kullanır: av ve oyun [Rus ruleti/bahis oyunları]. Birinci metafor filmde de gönderme yapılan James Fenimore Cooper'n Geyik Katili (1841) romanından alınmıştır. Cooper'ın romanındaki Natty Bumppo karakteri ile Avcı filmindeki Michael karakterleri arasında birçok benzerlikler vardır: her iki karakter de başka bir insanı öldürme zorunluluğunu ve savaşı ilk defa deneyimleyen çok yetenekli avcılardır; her ikisi de düşmanlar tarafından esir alınırlar, yani yerliler ve Vietnamlılar tarafından; her ikisi de erkeklerle takılmayı tercih etmekte ve kadınlardan çekinmektedir; her ikisi de 'tek atışı' kendisine erkeklik düsturu edinmiştir ${ }^{21}$. (Chong 94)
\end{abstract}

Ancak yukarıdaki alıntıda değinilen benzerlikler bizim çalışmamızda sayılamayacak kadar çok ve çeşitlidir, biz bu çalışmamızda Alageyik ve Avcı filminde kullanılan geyik imgesini karşılaştırmalı olarak incelemeye çalışacağız.

Filmin orijinal isminin her kelimesini tam olarak çevirecek olursak “Geyik Avcısı"dır ki, bu da filmin ele aldığı Vietnam Savaşı’nı da göz önüne alırsak, savaşa katılan, savaşta yaralanan ya da ölen tüm askerleri temsil etmektedir kanaatindeyiz çünkü tıpkı geyik avında olduğu gibi bu emperyalist savaşta da askerler geyik gibi, gencecik diğer askerleri, birbirlerini tuzağa düşürerek avlamaya çalışmaktadırlar. Bu nedenle, Frank Burke gibi bazı film eleştirmenleri Avcı filmini "emperyalizmin öldürücü/yıkıcı sonuçlarını empatiyle, bir bütünlük içinde anlattı̆̆ını” (27) ileri sürmektedir. Nitekim, savaşta sadece insanlar değil, o zamanlar "bir tarım ülkesi olan Vietnam'ın" (bakınız Burke, 22,24,25,26) doğal güzellikleri ve tabiatı da tahrip edilmiştir ve emperyalizmin hem insan hem de doğa üzerindeki yıkıcı etkileri filmde gözler önüne serilmektedir.

Filmdeki olay örgüsüne bakılacak olursa, Avcı filmi adeta yaşamın tüm renklerini barındırırcasına bir düğün sahnesi ile başlayarak, cenaze sahnesi ile son bulmaktadır. Amerika'da Clairton'da bir kasabada (Pennyslyvania) çelik üretiminin yapıldığı bir fabrikada çalışan ("The Regeneration of America: Uses of Landscape in "The Deer Hunter") Michael Vronsky/Mike (Robert De Niro), Nikonar/Nick Chevotarevich (Christopher Walken) ve arkadaşları yakın dostları Steven'ın (John Savage) dügününde hep birlikte seyirciye tanitılırlar.

21 The Deer Hunter employs two metaphors to describe the Vietnam War: the hunt and the game. The first metaphor derives from the allusion within the film to James Fenimore Cooper's novel The Deerslayer (1841). There are many similarities between the characters of Natty Bumppo in Cooper's novel and Michael in the film: both men are skilled hunters who experience war and the need to kill another human being for the first time; both are taken captive by their respective enemies, the Indians and the Vietnamese; both eschew the company of women, preferring male camaraderie; and both espouse the hunting philosophy of the "one shot" as the measure of masculinity. (Chong, 94)

Adres Address

RumeliDE Dil ve Edebiyat Araştırmaları Dergisi Osmanağa Mahallesi, Mürver Çiçeği Sokak, No:14/8 Kadıköy - ISTANBUL / TURKIYE 34714 e-posta: editor@rumelide.com

RumeliDE Journal of Language and Literature Studies Osmanağa Mahallesi, Mürver Çiçeği Sokak, No:14/8

Kadıköy - ISTANBUL / TURKEY 34714 tel: +90 $5057958124,+902167730616$

e-mail: editor@rumelide.com,

phone: +90 $5057958124,+902167730616$ 
A comparative approach to deer motif in the movies, The Red Deer and The Deer Hunter/ F. Kalpaklı (pp. 10961112)

Yukarıda adı geçen bu genç adamlar çok yakında Vietnam Savaşına katılacaklardır ve düğün onlar için hem bir eğlence, kutlama hem de bir veda gecesidir. Düğün gecesi, Mike gökyüzünde bulutların arkasında yalancı güneşi (sundogs) görür ve bunun yerliler arasında kurtların avcıya gönderdiği bir işaret olduğunu; av için iyi bir zaman olduğunun işareti olduğunu söyleyerek, arkadaşlarını "av partisi" yapmak için ikna eder. Böylece, düğün gecesinin ardından Mike, Nick, ve diğer arkadaşları Axel (Chuck Aspergren), Stan (John Cazale), ve John (George Dzundza) hep beraber dağlara giderek geyik avına çımaya karar verirler. Avcı filminde de tıpkı Alageyik filmindeki Halil gibi, bu genç adamlar avı düğün eğlencelerinden daha cazip bulmaktadırlar.

Filmde, Clairton kasabasının gri ve kirli havasından sonra dağlar, ağaçlar ve sular Mike ve arkadaşlarına adeta cennetten bir köşe sunmaktadır. Nick, "[s]on nefesimi dağlarda vermeye aldırmam. Ben ağaçları, dağları severim, Vietnam başka” (“Avcı”) diyerek Mike’a ne olursa olsun kendisini Vietnam'da bırakmamasını ve onu memleketine, dağlara geri getirmesini söyler.

Avcı (1978) filminde, Mike Alageyik'in Halil'i gibi tam bir geyik avı meraklısıdır; arkadaşlarına geyiklerin acı çekmemeleri için "tek atışta" vurulmaları gerektiğini anlatır durur. Fakat, Mike'ın bu yaklaşımı "diğer arkadaşları tarafından göz ardı edilir”(Boyd, 42). Bu bağlamda, aşağıda verilen Mike ile Nick arasındaki diyalogę 22 önemlidir:

Nick: Tek atış artık beni ilgilendirmiyor.

Mike: Tek atışı düşünmek zorundasın - Tek atış herşeyin özü - İnsanlara anlatmaya çalıştı̆̆ım bu yine de anlamiyorlar" (Aktaran Boyd, 42).

Mike ava çıtığında ise genelde dağlarda geyiği tek başına izlemeyi tercih etmektedir ve filmin yönetmeni Cimino, Mike’ın toplumunun bir temsilcisi olarak, hem de toplumundan ayrı olarak dağlarda tek başına oluşunu "onun gücüne” (Fox, 22) işaret olarak göstermektedir. Filmdeki Mike karakteri hem Amerikan yerlilerinin hikâyelerinden hem de Geyik Katili romanından izler taşımaktadır. Örneğin,

Cooper'ın anlatımları Amerikan yerli mitolojisini doğrulayarak "av adamın ve hayvanın evliliği olarak nitelendirilir.... Avcı öldürme anında avı ile bir olduğundan, avına denk ve uygun bir rakip olmak için kendisini hazırlamalıdır. Öldürme anında, hükmettiği ve öldürdüğü şeyin gücünü üstlenir ve bu nedenle, avcı karakterini ve yeni adını kurbanından almaktadı”. (Aktaran Chong, 94)

Bahsi geçen avlanma sürecinde, Mike adeta öldürdüğü hayvanların gücünü ve karakterini üstüne almakta, avıyla bir olmakta ve böylece adeta kaderin bir cilvesi olarak ileride katılacağı Vietnam Savaşı'na kendini hazırlamaktadır. Savaşta çok işine yarayacak olan bir geyiğin çevikliğini, iz sürmeyi ve izini kaybettirmeyi, avıyla bir olduğu bu anlarda öğrenmektedir. Fakat henüz savaşın vahşeti ile yüz yüze gelmediğinden, dağlarda huzurlu ve mutludur.

Geyik avına çıktığı zamanlarda, dağlarda geyiklerle adeta ulvi bir saklambaç oynamaktadır. Bu sahnelerde, filmin arka fonunda kilise müziği duyulmaktadır; sanki Mike ile geyik arasında kutsal bir dans, kutsal bir ritüel yaşanmaktadır. Mike ile geyik arasındaki kovalamaca ve kaçma sahnesi ve müzik aynı zamanda seyircinin kafasında geriye dönük, düğün sahnesine dönük çağrışımlar yapmaktadır. Düğün sahnesinde de, Mike ile Linda (Meryl Streep) çoşkulu bir şekilde dans ederken, geyiğin dağlarda seke seke kaçmasıyla, Linda'nın düğünde seke seke oynaması ve ikilinin birbirine ürkek ve kaçamak

22

... the code of the 'one shot, a code dismissed by the others, even by Nick, as mere idiosyncrasy ("To tell you the truth, I don't think much about 'one shot' anymore") , but maintained by Michael, through an almost desperate assertion of will, as a moral imperative ("You have to think about one shot -- one shot is what it's all about -- I try to tell people that - they don't understand") (Boyd, 42).

RumeliDE Dil ve Edebiyat Araştırmaları Dergisi Osmanağa Mahallesi, Mürver Çiçeği Sokak, No:14/8 Kadıköy - ISTANBUL / TÜRKIYE 34714 e-posta: editor@rumelide.com tel: $+905057958124,+90216773$ o 616

Address

RumeliDE Journal of Language and Literature Studies

Osmanağa Mahallesi, Mürver Çiçeği Sokak, No:14/8

Kadıöy - ISTANBUL / TURKEY 34714

e-mail: editor@rumelide.com,

phone: +90 $5057958124,+90216773$ o 616 
bakışları arasında paralellikler kurulmaktadır. Mike bu danslarda da bir geyik avcısından bir gönül avcısına dönüşmüştür; Linda da tıpkı bir geyik gibi ürkek gözlerle Mike’nın bakışlarını izlemektedir. Tabi düğün sahnesinde, arka fonda, kıvrak Rus müzikleri çalmaktadır. Düğünde çalınan müzikler ve düğün merasiminin yapıldığı kilise Clairton kasabasındaki işçilerin Rus Ortodoks kökenini gözler önüne sermektedir. Rus kökenli bu işçilerin çoğunluğu Clairton Demir Çelik fabrikasında çalışmaktadır. Binbir umutla geldikleri bu firsatlar ülkesi, Amerika'ya her alanda hizmet etmeye hazırdırlar ve aralarından bir kısmı gözlerini kırpmadan Vietnam Savaşı’na katılmaya karar vermişlerdir bile. Filmdeki av sahnesi ve geyik öldürme, ilerleyen zamanlarda yerini savaş sahnelerine ve insan öldürmeye bırakacaktır.

Mike dağlarda dolaşırken güzel bir geyik avlar ve geyiğin gösterişli boynuzlarını vurgulayacak bir biçimde, geyiği beyaz Impala arabasının önüne koyarak, bir kahraman edasıyla akşam kasabaya geri döner. Bu sahne de, bize Halil’in Alageyik filminde geyiği omzuna atarak, kasaba halkı şenlik yaparken onlara sunmasını andırmaktadır. Tabii bir farkla, Halil'in atının yerini bu sefer sanayileşmeyle birlikte Mike'ın beyaz otomobili almıştır. Otomobilin markasının Impala'an, yani bir geyik cinsinden alınmış olması da kayda değerdir. Böylece, Avcı filminde, Amerika'nın sanayi toplumuna geçiş süreci ile Mike ve Nick’inin dağlara olan tutkusu ve onların doğaya olan özlemi daha da vurgulanmaktadır.

Bir sonraki sahnede, Mike ve arkadaşlarını Vietnam'ın yemyeşil köylerinde ama müthiş bir ateş altında olduklarını görürüz. Bu sefer, geyik avı değil, gerçek bir insan avı vardır meydanda; çocuklu Vietnam'lı bir kadının vuruluşuna şahit oluruz. Alageyik Efsanesinde, hamile geyiklerin vurulması hoş görülmezken, savaşta çocuklu kadınlar büyük bir soğukkanlllıkla öldürülmekte, katledilmektedir. Amerikan askerleri, Mike ve arkadaşları da içlerinde olmak üzere esir düşerler. Suyun içinde adeta avcılar tarafından tuzağa düşürülen geyikler gibi kafeslere kapatılarak işkence edilirler. Kuzey Vietnamlı askerler, Amerikalı askerleri Rus ruleti oynamaya zorlarlar. Bu baskıya dayanamayan, Steven sinir krizi geçirir, ancak Mike bir yolunu bulup bir geyik çevikliği ile onu ve Nick’i alarak esir kampından kaçmayı başarır. Sonunda, onlar yüzerek nehirde kaçarken Amerikan helikopterleri onları bulur. Bu esnada, Steven bacaklarını kaybeder, Nick ise savaş travması nedeniyle pek kendinde değildir artık ve gece kulüplerinde Rus ruleti/bahis oynayarak, hayatını tehlikeye atarak adeta kendini öldürmeye çalışmaktadır.

Mike Amerika'ya evine geri döndüğünde, Linda ile daha da yakınlaşır. Bir süre sivil hayata alışmaya çalışır, hatta arkadaşlarıyla birlikte tekrar geyik avına gider. Ne var ki yaşadıkları onu değiştirmiştir, Mike'ın savaş sonrası, geyik avı esnasında yaşadıkları detaylı bir şekilde incelemeye değer niteliktedir.

Filmdeki dağ sahnelerinde, geyik Mike’ı peşinden koşturur; adeta ona dağda rehberlik eder. Mike büyük bir heyecanla bir süre geyiği takip eder ve en nihayetinde onu vurmaktan vazgeçer. Geyiğin yaşamasına izin verir, diğer bir deyişle geyiğin yaşam hakkına saygı duyar. Hatta bir sahnede, çă̆layan suyun başında oturup geyik ile konuşur. Mike "yaşamın kutsallı̆̆ı"nı kabul ederek, geyiği özgür ve diri olarak bırakır; arkadaşlarına da hedefi vuramadığını söyler. Bu sahnede, Mike’ın "geyiği öldürmeyi reddetmesi, [aynı zamanda] onun olgunlaştı̆̆ını göstermektedir24” (Fox, 23). Mike olgunlaşmıştır, savaştan önceki sahnelerde geyikleri öldürmekten çekinmediğini ve belki bundan bir çeşit haz aldığını da söyleyebiliriz. Vietnam Savaşı'na katılmadan önce, Mike daha toy ve daha acımasızdır. Geyik avına çıtığında sanki bir çeşit tanrıcılık oyunu oynamaktadır; avının, geyiklerin yaşayıp yaşamayacağına karar vermek onun

Otomobil markası olarak seçilen isim de o sıralar Amerika'da yaşanan sosyo-kültürel değişimin, sanayileşmenin sembolüdür adeta, eskiden impala deyince insanların ilk aklına gelen bir çeşit geyik türü iken, şimdilerde metal yığını ve etrafa egzoz gazı saçan otomobiller gelmektedir ve otomobil sahibi olmak bir çeşit statü göstergesidir. “De Niro's subsequent refusal to kill the deer at the end of the film indicates his growth” (Fox, 23).

Adres $\mid$ Address

RumeliDE Dil ve Edebiyat Araştırmaları Dergisi $\quad$ RumeliDE Journal of Language and Literature Studies Osmanağa Mahallesi, Mürver Çiçeği Sokak, No:14/8 $\quad$ Osmanağa Mahallesi, Mürver Çiçeği Sokak, No:14/8 Kadıköy - ÍSTANBUL / TÜRKIYE 34714 Kadıköy - ISTANBUL / TURKEY 34714 e-posta: editor@rumelide.com e-mail: editor@rumelide.com, tel: +90 505 7958124, +90 2167730616 phone: +90 505 7958124, +90 2167730616 
A comparative approach to deer motif in the movies, The Red Deer and The Deer Hunter/ F. Kalpaklı (pp. 10961112)

elindedir ve bu ona kendini daha da güçlü hissettirmektedir. Vietnam Savaşı'ndan birçok acı tecrübelerle ve hayatın kutsallı̆̆ının hiçe sayıldığı birçok ana şahitlik ettikten sonra evine, Clairton’a döndüğünde ise Mike artık eski Mike değildir. Mike daha olgunlaşmış25 ve hayatın, yaşamın kutsallı̆̆ını idrak etmiştir; "Michael'ın ikinci avda geyiği öldürmeyi reddetmesi ya da başaramaması, avı zedelemekten ziyade, aksine avın ahlaki önemine yeni bir boyut katarak, [avı] daha da önemli kılmıştır” (Boyd, 42). Kanımızca Mike tanrıcılık oynamanın bir faydası olmadığını; kendisinin tanrı olmadığını ve evrenin merkezinde olmadığını, tıpkı diğer canlılar gibi kendisinin de bu evrenin ve düzenin bir parçası olduğunu, sıradan bir insan olup kimsenin canını almak gibi bir hakka sahip olmadığını idrak edip, bunu kabul edip dağdaki kulübesine geri dönmüştür.

Mike'ın bu olgunlaşmasına karşın bir önceki sahnede, bir avuç geyik avcısının, hep beraber diğer bir geyiği takip ettikleri ve geyik tam nehirden karşıya geçerken, bu avcıların suyun içindeki geyiği hunharca ve beceriksizce avladıklarını ve bu avcıların geyiğin acı çekerek yaşamını yitirmesinden de büyük bir zevk aldıklarını gözlemleriz. Bu sahnede ise henüz insanların ve avcıların doğaya ve diğer canlılara karşı davranışında daha alınacak uzun bir yolun olduğu gösterilmektedir.

Filmde bir sonraki sahnede ise, Mike'ın arkadaşları arasında, dağ kulübesinde ufak bir tartışma çıkar ve bu esnada, Mike Stanley'nin hep beraberinde taşıdığı küçük silahı elinden alarak uzaklara firlatıp atar. Mike'ın bu hareketini de sembolik olarak inceleyecek olursak, Mike'ın zaman içinde değişerek dönüşüme uğradığını ve ölümden ziyade yaşamı yeğlediğini, "yaşamayı ve yaşatmayı" amaçladığını söyleyebiliriz.

Bu bağlamda, Mike Nick'e verdiği sözü de unutmayacaktır ve Vietnam'a geri dönüp, onu Amerika'ya geri getirmeye çalışır. Tıpkı dağlarda geyiklerin izini sürdüğü gibi, Vietnam'da da büyük bir titizlikle Nick'in izini sürerek onu bulur. Nick'in çalıştığı gece kulübüne giderek ona dağları, ağaçları hatırlatarak, onu eve dönmeye ikna etmeye çalışır. Fakat Nick, doğadan ve kendi özünden kopmuştur bir kere, bileklerinde jilet izleri vardır, bakışları donuktur, sanki bir takım uyuşturucu maddelerin de etkisi altındadır, savaşın yarattığı birçok travmanın izlerini ruhunda ve bedeninde taşımaktadır. $\mathrm{O}$ dağlarından ${ }^{26}$, ağaçlarından uzaklara atılarak, köklerinden koparılmışır ve artık yaşayan bir ölüdür. Gelişmiş, mekanik silahlar hem onun ruhunu hem de masum Vietnamlı sivilleri yok etmektedir. Nick'in bakışlarının feri gitmiştir, tüm dünyadaki endüstrileşmeye paralel olarak o da mekanikleşmiş, özüne doğasına yabancılaşarak ruhunu kaybetmiştir sanki. Tüm bunlara rağmen, Mike hemen pes etmez; Nick’i dağlara, ait olduğu yere götürmeye kararlıdır. Nick adeta savaşta hayatta kaldığı için kendini suçlu hissetmektedir ve insan doğasına aykırı olan savaşta şahit olduğu bunca vahşetten sonra yaşamayı hak etmediğini düşünmektedir. Tüm bu düşüncelerin olumsuz tesiri altında, Nick Mike'a karşı Rus ruleti oynayarak, en nihayetinde kendini öldürür. Tıpkı geyik avında öğütledikleri gibi kendini de tek atışla öldürür. Mike çaresiz ve üzgün Nick’in naaşını Amerika’ya geri getirir. Böylece, Nick'e verdiği sözü tutmuştur, ne olursa olsun onu dağlara, toprağına, ait olduğu yere, vatanına geri getirmiştir.

Filmin son dakikalarında Nick'in cenaze töreni ve bunu müteakiben arkadaşlarının hep beraber cenaze yemeğinde “Tanrı Amerika'yı korusun (kutsasın)/God bless America” şarkısını söylediklerini görmekteyiz. Şarkının sözlerine kulak verilirse, bu şarkının Amerika’nın toprağına, suyuna, doğasına bir övgü olduğu görülür ki, bu da filmde insanın ölüm anında dahi toprakla olan bütünleşmesine bir vurgu

25 Michael's failure, or refusal, to kill the deer in the second hunt, serves not to diminish, but rather to enlarge and add a further dimension to the moral significance of the hunt (Boyd, 42).

26 Bazı eleştirmenler Mike'ı ve Nick'i birbirini tamamlayan avcı/savaşcı ve şaman olarak adlandırırlar. Avda ve savaşta, Mike daha atak ve disiplinlidir, Nick ise daha duygusal ve daha edilgendir; tıpkı bir Şaman gibi etrafinı gözlemleyerek anlamaya çalışmayı tercih eder (bakını Boyd, "The Deer Hunter: The Hero and the Tradition”, 49).

Adres | Address

RumeliDE Dil ve Edebiyat Araştrrmaları Dergisi $\quad$ RumeliDE Journal of Language and Literature Studies

Osmanağa Mahallesi, Mürver Çiçeği Sokak, No:14/8 $\quad$ Osmanağa Mahallesi, Mürver Çiçeği Sokak, No:14/8

Kadıköy - İSTANBUL / TÜRKIYE 34714 Kadıköy - ISTANBUL / TURKEY 34714

e-posta: editor@rumelide.com e-mail: editor@rumelide.com,

tel: +90 505 7958124, +90 216773 o 616 phone: +90 505 7958124, +90 2167730616 
olabilir kanaatindeyiz. Cenaze sonrası söylenen bu şarkı ile tüm karakterler anakronistik bir ekoeleştirel bilinçle adeta tıpkı Nick gibi hepimiz topraktan geldik, yaşanan her an, geçen her saniye ile birlikte toprağa daha da yakınlaşmakta ve toprağa gitmekteyiz; her damla suda, her toprak zerresinde gene hep beraber olacağız diye vurgulamaktadırlar. Nitekim hayat devam etmektedir ve yaşam ile ölüm iç içedir, içinde bulundukları an itibariyle yaşama tutunmaya, yaşamaya da devam edeceklerdir; bu doğanın içinde su gibi akan doğal yaşam döngüsüdür.

Bu sebepten ötürüdür ki film düğünle başlayıp, cenaze ile bitmektedir. Filmin son sahnesinin bir cenaze sahnesi olmasına rağmen, filmin sonunda genel olarak iyimser bir atmosfer hâkimdir diyebiliriz; çünkü film hayatın devam ettiğini simgeleyen geniş bir yemek masasında ve filmdeki esas topluluk hep beraber Tanrı Amerika'yı korusun/kutsasın şarkısını söylerken bitmektedir. Ayrıca, bu esnada, kamera da Mike'ın Linda'ya sevgi dolu bakışları üzerinde odaklanarak, bu sevgiyi seyirciyle paylaşmaktadır ki insanın özünde doğal olarak bulunan sevginin tüm acılara ve savaşlara rağmen bir yol bularak açı̆̆a çıtı̆̆ı her yerde yaşam ve umut hep vardır diye öne sürülebilir.

Tüm bu bilgilerin ve örneklemlerin ışığında denilebilir ki her şeye rağmen, Avcı filmi savaşlarla, silahlarla hem insan doğasına, hem de tüm evrendeki doğaya yapılan tahribata karşın, bunlardan ders alarak insanın tekrar özüne, doğaya dönerek sevgiyle yaşayabileceği ve yaşatabileceği mesajını vererek sona ermektedir.

Sonuç olarak Alageyik ve Avcı filmlerine karşılaştırmalı27 bir bakış açısıyla bakıldığında diyebiliriz ki, her iki film de romanlardan beyazperdeye aktarılmıştır ve her ikisi de yerel halk hikâyelerinden öğeler taşımaktadır. Alageyik Anadolu halk efsanelerinin, Avcı da Amerikan yerlilerinin hikâyelerinin izlerini taşımaktadır. Her iki filmin ana karakteri de oldukça gözü pek, mert eril karakterlerdir. Sevdiklerine ve arkadaşlarına, içinde yaşadıkları topluma karşı merhametli ve koruyucu, düşmanlarına karşı acımasız ve serttirler. Alageyik filminde Halil köy ağasına karşı, Avcı filminde ise Mike, Kuzey Vietnam'lı askerlere karşı seyircinin üzerinde hayranlık uyandıran bir şekilde karşı koymaktadırlar. Hem Halil'in hem de Mike'ın gözü karadır; doğru bildikleri için mücadele etmekten, savaşmaktan korkmazlar. Diğer ilginç bir benzerlikleri ise ilk başlarda özgürlüklerine çok düşkün olup, sevdikleri kadınların yanında olmaktansa, geyiklerin yanında olmayı tercih etmeleri, ancak daha sonra her ikisinin de geyiklerin ruhsal rehberliği sonrasında ehlileşerek geyik avcılığından gönül avcılı̆̆ına terfi ederek, filmlerin son sahnelerinde sevdikleri kadınların yanında yer almalarıdır. Artık hem Halil hem de Mike daha ehlileştirilmiş ve daha dingindirler.

Her iki filmdeki en belirgin benzerlik ise hem Halil'e hem de Mike'e dağlarda geyikler tarafından ruhsal rehberlik edilmesidir ki bu nokta her iki ana karakterin de içsel yolculuğunda onlarda farkındalık yaratarak çok büyük bir dönüşüm ve değişim sağlamıştır. Rehber geyikler her iki karakterin de içindeki "yaşama sevgisini” ve "yaşama saygısını" ortaya çıkarıp, her iki avcının da kendi aczini ve aynı zamanda gücünü keşfetmesini sağlayarak onların iç sesleriyle temasa geçmelerini sağlayıp, onları avcılıktan insanlı̆̆a yükseltmişlerdir. Filmin sonunda, Halil “tövbe geyik avına” diyerek, Mike da kovaladığı geyiği vurmayı kasıtlı olarak "skkalayarak", can almaktan vazgeçerek, yaşama saygıyı ve doğaya hükmetmektense, doğanın bir parçası olmayı tercih ederek binlerce sinema izleyicisine de güzel birer rol model olmuşlardır. Böylece, "doğanın içinde insanoğlunun sadece küçük bir parça olduğunu bütün

$27 \quad$ Alageyik ve Avcı filmlerinin isimlerine, başlıklarına bakılınca, Alageyik filminde film başlığında odak noktasının geyik olduğu; Avcı filminde ise Amerikan kültürünün ve Amerikan bireyselliğinin/bireyciliğinin bir yansıması olarak da geyikten ziyade, Amerikalı bireyin, yani avcının ön plana çıktığı görülmektedir. Bu bağlamda, Alageyik filminin Avcı filmine göre, insan merkezli olmaktan uzak ve daha geyik merkezli olduğu görülmektedir. Bu nedenle, Alageyik filminin insandan ziyade geyiği ön plana çlkararak daha eşitlikçi, daha doğa dostu bir tutum sergilediği söylenebilir. Adres Address

RumeliDE Dil ve Edebiyat Araştırmaları Dergisi $\quad$ RumeliDE Journal of Language and Literature Studies Osmanağa Mahallesi, Mürver Cicceği Sokak, No:14/8 Osmanağa Mahallesi, Mürver Çiçeği Sokak, No:14/8 Kadıköy - İSTANBUL / TÜRKIYE 34714 Kadıköy - ISTANBUL / TURKEY 34714 e-posta: editor@rumelide.com $\quad$ e-mail: editor@rumelide.com, tel: +90 $5057958124,+90216773$ o 616 phone: +90 505 7958124, +90 216773 o 616 
A comparative approach to deer motif in the movies, The Red Deer and The Deer Hunter/ F. Kalpaklı (pp. 10961112)

varlığıyla hisseden” (Alpaslan: 2014, “Türk Şiirinde Doğa Algısı...”, 90) seyirci de Alageyik ve Avcı filmleri aracılığıyla kendisinin de diğer canlıların yaşam hakkını ihlal etmeden, doğayla uyum içinde yaşaması ve çevre etiğini hayatına aktarması gerektiğinin bilincine erişerek, tüm dünyada çevre ve çevre sorunları üzerine farkındalığı artmış olarak sinema salonlarını terk etmektedir ki bu da edebiyat ve sinema gibi sanatların doğa sevgisi ve çevre etiğinin aşılanmasında son derece önemli, vazgeçilmez unsurlar olduğunun güzel bir göstergesidir.

\section{Kaynakça}

\section{Ana kaynakça}

Gür, Şeref \& Hürrem Erman (Yapımcı), Güney, Yılmaz\&Halit Refiğ \& Atıf

Yllmaz (Senarist) ve Yllmaz, Atıf (Yönetmen). (1959) Alageyik [Sinema Filmi]. Türkiye: Erman Film.

Köseoğlu, Murat. (Yapımcı), Tünaş, Erdoğan (Senarist) ve Duru, Süreyya

(Yönetmen). (1969) Alageyik [Sinema Filmi]. Türkiye: Erman Film.

Spikings, Barry ve Michael Deeley (Yapımcı), Michael Cimino ve Deric Washburn

(Senarist) ve Cimino, Michael (Yönetmen). (1978) . Avcr [Sinema Filmi]. Amerika: EMI Film.

\section{İnternet kaynakçası}

“Avcl”, Erişim adresi: http://www.beyazperde.com/filmler/film-29714/ Erişim tarihi: 9. Ekim.2020.

"Avcl”, Erişim adresi: https://www.sinemalar.com/film/1158/avci. Erişim tarihi: 13. Ekim.2020.

"Avcr Afiş ”, Erişim adresi: https://www.posterlounge.com/p/345876.html. Erişim tarihi:23. Ekim.2020.

“Alageyik filmi”, Erişim adresi: https://tr.wikipedia.org/wiki/Ala_Geyik_(film,_1969). Erişim tarihi: 11. Şubat. 2016.

“Alageyik”, Erişim adresi: https://tr.wikipedia.org/wiki/Alageyik. Erişim tarihi: 13. Şubat. 2016.

"Alageyik Afiş ”, Erişim adresi: http://www.sinematurk.com/film/1547-ala-geyik/ Erişim tarihi: 24 Mayis 2017.

“Alageyik Afiş ”, Erişim adresi: http://www.tsa.org.tr/tr/film/ekip/912/ala-geyik, Erişim tarihi: 24 Mayıs 2017.

Alpaslan, Gökalp Gonca. (2014). “Cengiz Aytmatov’un Elveda Gülsarı, Dişi Kurdun Rüyaları, Ebedi Gelin: Dağlar Yıkıldığı Zaman Romanlarında Hayvan Zihni”. Türklük Bilimi Araştırmaları. Yıl:19, Sayı:36. 11-26.

Alpaslan, Gökalp Gonca (2014). “Türk Şiirinde Doğa Algısına Dair Betimleyici Bir Bakış”, Kültür Ötesi Bir Gezgin. Ed. Mustafa Pultar. İstanbul: Tetragon. 79-95.

Baran, Evin Sevgi. (2018). Bir Direniş Biçimi Olarak Sinema, Hacettepe Üniversitesi Sosyal Bilimler Enstitüsü Sosyoloji Anabilim Dalı Yüksek Lisans Tezi, Ankara.

Bonnefoy, Yves (Yön.) (2000). Antik Dünya ve Geleneksel Toplumlarda Dinler ve Mitolojiler Sözlüğü. Çev. Levent Yllmaz. Ankara: Dost Kitabevi.

Boyd, David. (1980). "The Deer Hunter: The Hero and the Tradition", AJAS. July, Vol. 1, No. 1 pp. 4151. Australia New Zealand American Studies Association. Erişim adresi: https://www.jstor.org/stable/41053283

Burke, Frank. (1983). “In Defense of 'The Deer Hunter' OR: The Knee Jerk is Quicker than the Eye”, Literature/Film Quarterly. Vol. 11, No. 1. 22-27. Salisbury University. Erişim adresi: https://www.jstor.org/stable/43797290.

Chong, Sylvia Shin Huey. (2005). "Restaging the War: 'The Deer Hunter' and the Primal Scene of Violence”, Cinema Journal, Winter, 2005, Vol. 44, No. 2 (Winter, 2005), pp. 89-106. University

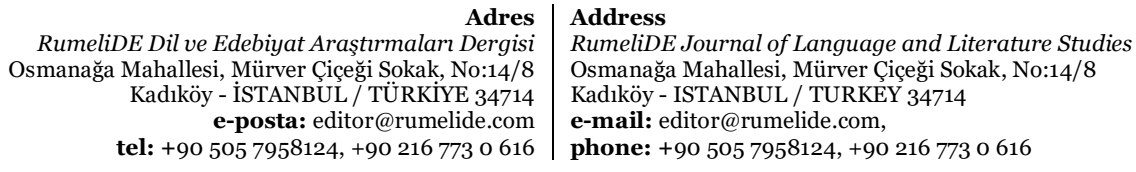


of Texas Press on behalf of the Society for Cinema \& Media. Studies. Erişim adresi: https://www.jstor.org/stable/3661096.

Cüceloğlu, Doğan. (2015). Damdan Düşen Psikolog. İstanbul: Remzi.

Francis, Don. (1983), "The Regeneration of America: Uses of Landscape in "The Deer Hunter"'Literature/Film Quarterly, Vol. 11, No.1, pp. 16-21. Salisbury University Press, Erişim adresi: https://www.jstor.org/stable/43797289.

Fox, Terry Curtis. (1979). “Stalking 'The Deer Hunter'”, Film Comment, MARCH-APRIL, Vol. 15, No. 2, pp.22-24, Film Society of Lincoln Center. Erişim adresi: https://www.jstor.org/stable/43451041.

"Hayvanların Bilmediğiniz Özellikleri”, Erişim adresi: https://www.haber7.com/foto-galeri/54313hayvanlarin-bilmediginiz-ozellikleri/p13. 06.07.2018. Erişim tarihi:11.Ekim.2020.

“İhram Nedir?”, Erişim adresi: http://www.on5yirmi5.com/haber/inanc/islam/92574/ihram-nedirihram-yasaklari-nelerdir.html_Erişim_tarihi__4 Mart 2016.

Türkiye Radyo ve Televizyon Kurumu (Yapımc1). Kadim [Belgesel]. (5. Mart. 2017). Ankara: TRT Haber.

Kara, Mesut. "Sinema'nın Yaşar Kemali”. Erişim_tarihi: 23 Mayıs 2017. Erişim adresi: (https://www.evrensel.net/yazi/73599/sinemanin-yasar-kemali)

Karadavut, Zekeriya \& Ünsal Yllmaz Yeşildal. (2007) “Anadolu-Türk Folkloründe Geyik”, Milli Folklor. Yıl 19, Sayı: 76. 102-112. Millifolklor.com.

Kumartaşlıŏ̆lu, Satı. (2016) “Geyik Boynuzlarının Yatırlarda Şifa İçin Kullanımı”, Erişim adresi: millifolklor.com. 137-148. Erişim tarihi:1 Mayıs 2016.

Lyng, Eoghan. "One Shot: The making of Michael Cimino film 'The Deer Hunter", 20 Aralı 2019, Erişim adresi: https://faroutmagazine.co.uk/making-of-michael-cimino-film-the-deer-hunter/. Erişim tarihi: 10.Ekim.2020.

Onur, Gülbün. (2016) "Türk Filmlerinde Değişen ve Değişmeyen Karakterler/ Flat and Round Characters in Turkish Films". Turkic Art Symposium. 12 Mayı 2016. Konya.

Oppermann, Serpil and Ufuk Özdağ. (2011). "Introduction: New Connections in Ecocriticism”, The Future of Ecocriticism: New Horizons. Ed. Serpil Oppermann, Ufuk Özdağ, Nevin Özkan and Scott Slovic. Newcastle upon Tyne: Cambridge Scholars Publishing. 1-8.

Ögel, Bahaeddin. (2014). Türk Mitolojisi. II. Cilt. Ankara: Türk Tarih Kurumu.

Öztürk, Yaşar Nuri. (2014). Kuran-ı Kerim Meali (Türkçe Çeviri). İstanbul: Yeni Boyut.

Özdağ, Ufuk. (2014). Çevreci Eleştiriye Giriş- Doğa, Kültür, Edebiyat. Ankara: Ürün.

Özgüç, Agah. "Yaşar Kemal Filmleri”, Cumhuriyet Dergi. 30. Ağustos.1992. sy. 4-5 Şehir e-arşiv. Erişim adresi: earsiv.sehir.edu.tr:808o/xmlui/bitstream/handle/11498/37124/oo1519750oo6.pdf?... Erişim tarihi: 20. Mayls. 2017.

Quadir, Tarık Masud. (2017) "Islam and Sustainability: The Norms and The Hindrances", Routledge Handbook of The History of Sustainability. Ed.Jeremy L. Caradonna. London: Routledge. 120135 .

Seyidoğlu, Bilge. (1985).Erzurum Efsaneleri. Ankara: [yaynnevi belirtilmemiş].

Sakaoğlu, Saim. (1992). Efsane Araştırmaları. Konya: Kömen.

Şahin, Hülya Dündar (2015) “Geyikler, Annem ve Almanya'da Geyik Motifi”, TUKAS- Türk Kültürü Araştırmaları Sempozyumu Kitabı-Hacı Bektaşi Veli Üniversitesi. Nevşehir: Hacı Bektaş Veli Üniversitesi Yayınları. 67-74.

Şahin, Elmas. (2014). “Alageyik ile Avcının Ölümcül Dansı”, Turkish StudiesInternational Periodical For The Languages, Literature and History of Turkish or Turkic Volume 9/12. Fall 2014,

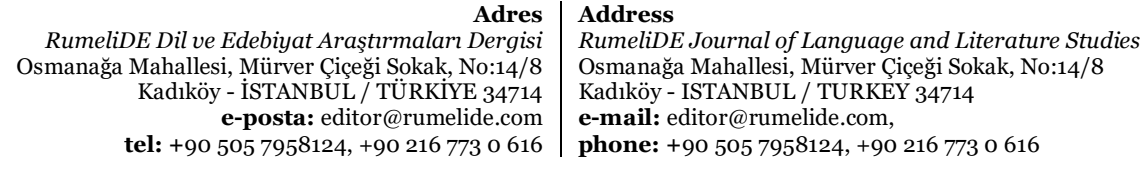


A comparative approach to deer motif in the movies, The Red Deer and The Deer Hunter/ F. Kalpaklı (pp. 10961112)

Ankara. 633-646. Erişim adresi:

http://turkishstudies.net/Makaleler/1414684529_35\%C5\%9EahinElmas-edb-633-646.pdf.

Cuma Sohbetleri. 4 Mart 2016. Erişim adresi: https://www.youtube.com/watch. Erişim tarihi: 15 Mart 2016.

“Geyikler/Alageyik/Fallow Deer/ Dama dama”, Erişim adresi:

http://www.tramem.org/memeliler/?fsx=2fsdl17@d\&tur=Alageyik. Erișim tarihi: 12 Mart 2016.

“Tür Koruma Stratejisi - Doğa Koruma ve Milli Parklar”, Nisan 2014, Ankara, Erişim adresi: www.milliparklar.gov.tr/.../TÜR_KORUMA_STRATE...Erişim tarihi: 12 Mart 2016.

Tevrat. (2015). Yayına Hazırlayan: Hasan İlhan. Ankara: Andaç.

Tunalı, Berk. (2009). 27 Mayıs 1960 ve Toplumsal Değişimlerin Türk Sinemasına Yansıması: Toplumsal Gerçekçilik. İstanbul Üniversitesi Sosyal Bilimler Enstitüsü Radyo, Televizyon ve Sinema Anabilim Dalı. Yüksek Lisans Tezi.

Varol, Fahrettin. (2016). Yllmaz Güney’in Sinemasının İdeolojik ve Gerçekçi Sinema Dilinin Çözümlenmesi, Ordu Üniversitesi, Sosyal Bilimler Enstitüsü Sinema ve Televizyon Anabilim Dalı, Yüksek Lisans Tezi.

Wright, Charles. (1868). "Deer and Deer-Hunting in Texas", The American Naturalist, Vol. 2, No. 9 (Nov.), 466-476.The University of Chicago Press. 22-02-2017. Erişim adresi: http://www.jstor.org/stable/2447205.

\section{Teşekkür notu:}

Çevre çalışmaları ve toprak etiği alanında bana rehberlik ederek önümde yeni ufuklar açan ve ayrıca, bu çalışmanın yıllar içinde olgunlaşmasındaki katkıları için Sayın Prof. Dr. Gonca Gökalp Alpaslan ve Prof. Dr. Ufuk Özdağ hocalarıma sonsuz teşekkürlerimi sunarım.

\section{Film afişleri:}

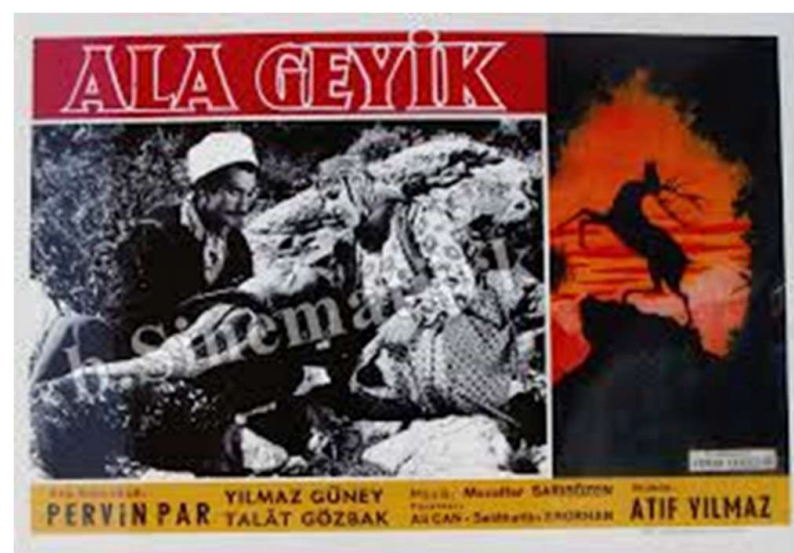

Erişim adresi: http://www.sinematurk.com/film/1547-ala-geyik, Erişim tarihi: 24 Mayıs 2017.

Adres
RumeliDE Dil ve Edebiyat Araşttrmaları Dergisi Osmanağa Mahallesi, Mürver Çiçeği Sokak, No:14/8 Kadıköy - ÍSTANBUL / TÜRKIYE 34714 e-posta: editor@rumelide.com tel: +90 $5057958124,+902167730616$
Address

RumeliDE Journal of Language and Literature Studies Osmanağa Mahallesi, Mürver Çiçeği Sokak, No:14/8

Kadıköy - ISTANBUL / TURKEY 34714

e-mail: editor@rumelide.com,

phone: +90 5057958124, +90 2167730616 


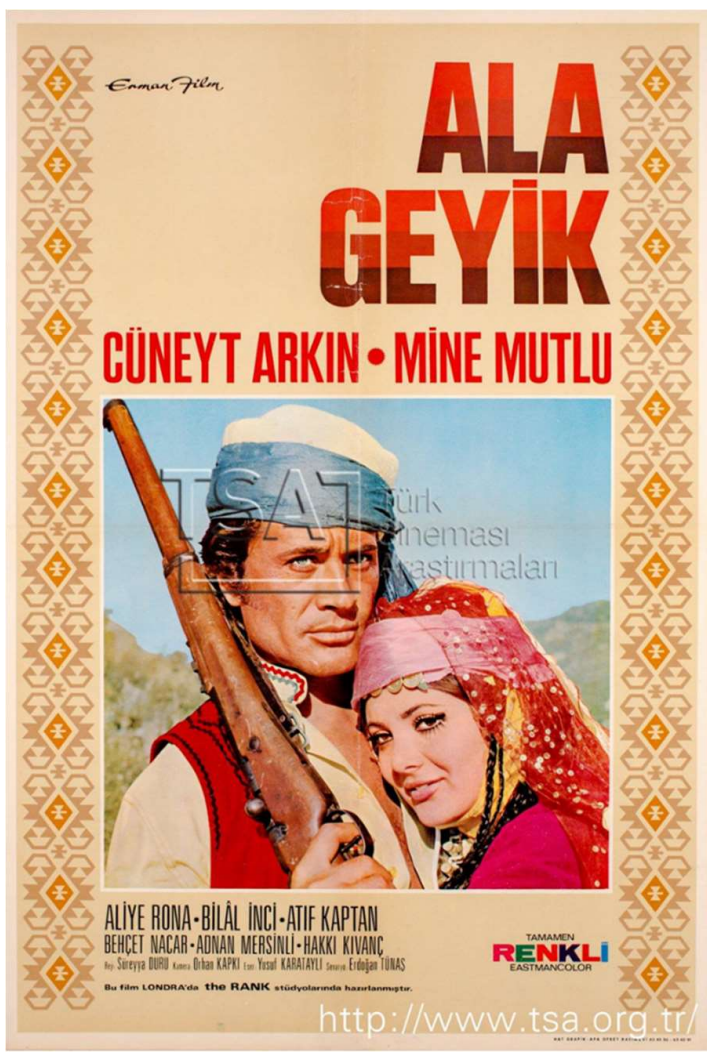

Erişim adresi: http://www.tsa.org.tr/tr/film/ekip/912/ala-geyik, Erişim tarihi: 24 Mayıs 2017

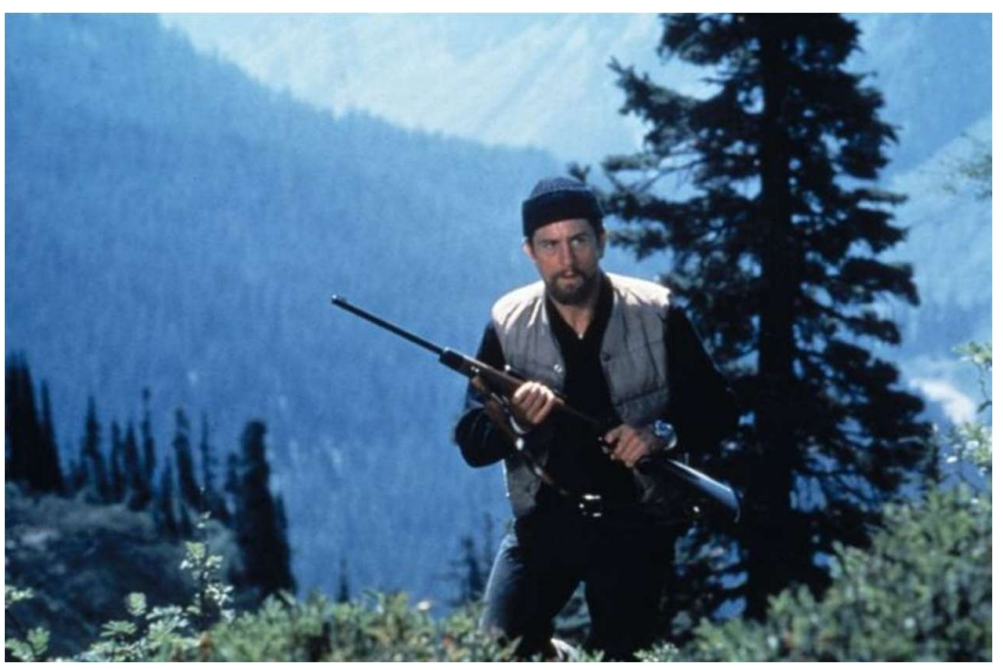

Erişim adresi: https://faroutmagazine.co.uk/making-of-michael-cimino-film-the-deer-hunter/. Lyng, Eoghan. "One Shot: The making of Michael Cimino film “The Deer Hunter”, 20 Aralık 2019, Erişim tarihi: 10 Ekim 2020.

Adres
RumeliDE Dil ve Edebiyat Araşturmaları Dergisi Osmanağa Mahallesi, Mürver Çiçeği Sokak, No:14/8 Kadıköy - ISTANBUL / TÜRKIYE 34714 e-posta: editor@rumelide.com tel: +90 505 7958124, +90 2167730616
Address

RumeliDE Journal of Language and Literature Studies Osmanağa Mahallesi, Mürver Çiçeği Sokak, No:14/8

Kadıköy - ISTANBUL / TURKEY 34714

e-mail: editor@rumelide.com,

phone: +90 $5057958124,+902167730616$ 
A comparative approach to deer motif in the movies, The Red Deer and The Deer Hunter/ F. Kalpaklı (pp. 10961112)

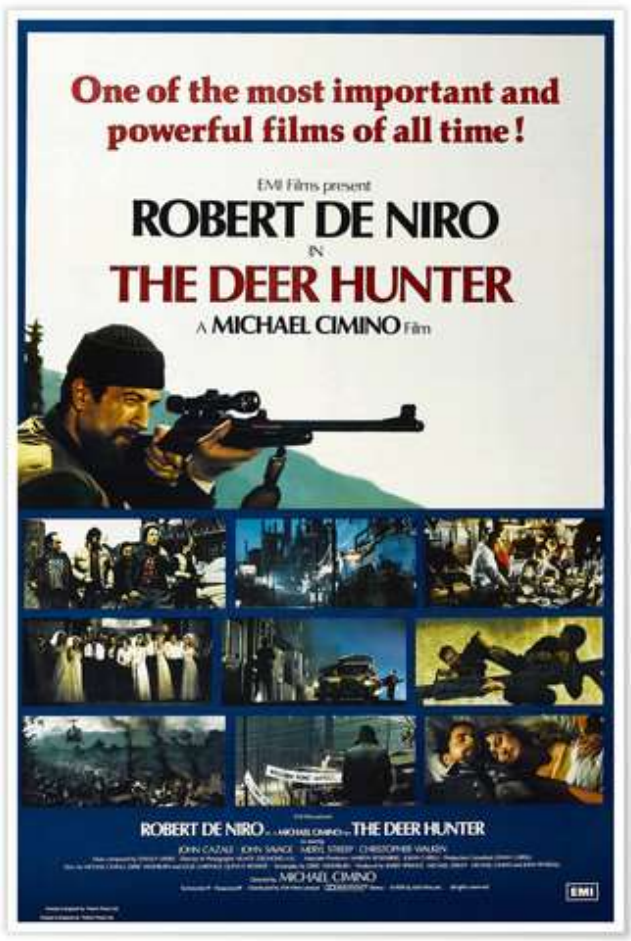

Erişim adresi: https://www.posterlounge.com/p/345876.html, Erişim tarihi: 23 Ekim 2020. 